\title{
Respiratory health effects of fifteen years of improved collective protection in a wheat-processing worker population
}

\author{
Victor Dorribo', Pascal Wild², Jacques A. Pralong', Brigitta Danuser', Gabriel Reboux³, \\ Peggy Krief ${ }^{* *}$, Hélène Niculita-Hirzel ${ }^{4^{*}}$ \\ ${ }^{1}$ Service of Occupational Medicine, Institute for Work and Health, University of Lausanne and Geneva, Epalinges-Lausanne, \\ Switzerland \\ ${ }^{2}$ INRS, Scientific Management, Nancy, France \\ ${ }^{3}$ Service of Parasitology and Mycology, CHU de Besançon, Besançon, France \\ ${ }^{4}$ Service of Occupational Hygiene, Institute for Work and Health, University of Lausanne and Geneva, Epalinges-Lausanne, \\ Switzerland
}

\footnotetext{
* Joint senior authors of the study
}

Dorribo V, Wild P, Pralong JA, Danuser B, Reboux G, Krief P, Niculita-Hirzel H. Respiratory health effects of fifteen years of improved collective protection in a wheat-processing worker population. Ann Agric Environ Med. 2015; 22(4): 647-654. doi: 10.5604/12321966.1185768

\begin{abstract}
Introduction. Occupational exposure to grain dust causes respiratory symptoms and pathologies. To decrease these effects, major changes have occurred in the grain processing industry in the last twenty years. However, there are no data on the effects of these changes on workers' respiratory health.

Objectives. The aim of this study was to evaluate the respiratory health of grain workers and farmers involved in different steps of the processing industry of wheat, the most frequently used cereal in Europe, fifteen years after major improvements in collective protective equipment due to mechanisation.

Materials and Method. Information on estimated personal exposure to wheat dust was collected from 87 workers exposed to wheat dust and from 62 controls. Lung function ( $F E V_{1}, F V C$, and PEF), exhaled nitrogen monoxide $\left(F_{E} N O\right)$ and respiratory symptoms were assessed after the period of highest exposure to wheat during the year. Linear regression models were used to explore the associations between exposure indices and respiratory effects.

Results. Acute symptoms - cough, sneezing, runny nose, scratchy throat - were significantly more frequent in exposed workers than in controls. Increased mean exposure level, increased cumulative exposure and chronic exposure to more than $6 \mathrm{mg} \cdot \mathrm{m}^{-3}$ of inhaled wheat dust were significantly associated with decreased spirometric parameters, including FEV

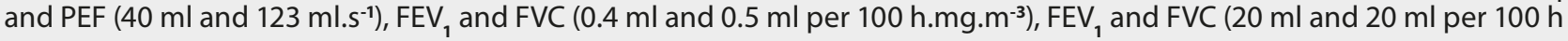
at $\left.>6 \mathrm{mg} \cdot \mathrm{m}^{-3}\right)$. However, no increase in $\mathrm{F}_{\mathrm{E}} \mathrm{NO}$ was associated with increased exposure indices.

Conclusions. The lung functions of wheat-related workers are still affected by their cumulative exposure to wheat dust, despite improvements in the use of collective protective equipment.
\end{abstract}

\section{Key words}

agricultural workers' lung diseases, occupational wheat dust exposure, dose-effect correlation model, collective protective equipment.

\section{INTRODUCTION}

Occupational exposure to grain dust is associated with both acute and chronic effects on the airways [1]. The main reported respiratory effects of exposure to grain dust are still asthma and acute asthma-like symptoms [2,3], reduced lung volume, and symptoms evoking chronic bronchitis $[4,5,6]$. However, the etiology of these effects is not completely understood, mainly due to the complexity and variety of potentially causative agents within grain dust. Indeed, grain dust is a generic name for the total dust generated by manipulating different varieties of cereal crops, and comprises variable microbial flora associated with multiple plants. This nonhomogenous exposure can be a limitation for establishing

Address for correspondence: Hélène Niculita-Hirzel. Service of Occupational Hygiene, Institute for Work and Health, University of Lausanne and Geneva, Route de la Corniche 2, CH-1066 Epalinges-Lausanne, Switzerland.

E-mail: Helene.Hirzel@hospvd.ch

Received: 19 November 2014; accepted: 09 December 2014 dose-response relationships in epidemiological studies. Thus, the few studies which reported until now dose-response relationships either with duration of exposure or current exposure levels to grain dust $[7,8]$, did not explore the impact of the task-specific exposure levels on respiratory health.

One way to clarify this issue is to focus on the populations exposed to one main type of crop dust. Working populations handling wheat grain or straw are one such population in western countries where wheat is the most intensively cultured cereal. The quantities of wheat generated require working populations with specialised task sets in the process of wheat harvesting and transformation. Harvesting workers are specialised in grain or straw harvesting. Terminal elevator operators are specialised for grain unloading, cleaning, storage and loading. Finally, livestock and dairy farmers, by intensifying their activity, see an increase in their exposure to wheat straw as livestock litter. Thus, all of these populations are exposed to wheat dust. Moreover, work-related respiratory effects have been proved, even after the 2000s, in terminal 
elevator operators [4], livestock and dairy farmers [2, 5, $9,10,11,12]$, and grain farmers [13], by epidemiological studies conducted on these populations. However, no data are available on populations of harvesters and straw ball makers, mainly because they are only seasonally exposed to wheat.

Since the 2000s, the collective and personal protection of operators in terminal lifts as well as of farmers has been greatly improved. The usage of new machines and infrastructures has been described to reduce the overall exposure to grain dust - and to wheat dust in particular - of grain workers and farmers [7, 14]. Nevertheless, some of the tasks associated with the usage of these new machines (compressed air cleaning of next-generation straw makers and combine harvesters) and technologies (straw choppers, chopped straw blowers) still entail a high level of dust exposure. Thus, an epidemiological study is needed to evaluate whether the currently used, collective and personal protective measures, are sufficient to prevent the development of lung pathologies in the different populations handling grain or straw.

The aims of the presented study were to include subjects from different wheat-dust exposed populations, to identify and assess semi-quantitatively, the present-day and previous dust-exposing tasks, and to document dose-response relationships with respiratory outcomes.

\section{MATERIALS AND METHOD}

The study was proposed by mail invitation to 1,100 farmers and harvesters, 10 terminal elevators and 500 workers not exposed to grain dust. From those who elected to participate in the study, 87 subjects were retained, drawn from the four working populations exposed primarily to wheat dust: terminal elevator operators (TEO), harvesters, livestock and grain farmers, and 62 workers not-exposed to grain dust. All subjects were from the Vaud region, which is the main granary region of Switzerland. The control population was composed of 30 rural and 32 urban inhabitants, all working in Lausanne, mostly in the medical care services or in their infrastructures (administration, cooking, mechanic, nurse, doctor, etc.). Exclusion criteria were an ongoing corticosteroid or immunosuppressant treatment, obesity (BMI $\left.>40 \mathrm{~kg} \cdot \mathrm{m}^{-2}\right)$, difficulty in understanding the questionnaire, or current inclusion in another study protocol. Characteristics of the study population are given in Table 1.

Data collection took place just after the period of typical highest exposure during the year to wheat dust for each working population, i.e., from August - September 2012 for TEO, harvesters and non-exposed subjects and in January - February 2013 for livestock and grain farmers.

Each population exposed to wheat dust conducted specific wheat related tasks:

The TEOs were in charge of wheat grain unloading, cleaning and loading, as well as in silo cleaning. Their level of exposure to wheat dust differed depending upon the constraints of the terminal elevator structure. In some terminal elevators, TEOs were working on the dock during wheat grain unloading, whereas in others they were working in an office, which may or may not have been isolated from the unloading site. Individual protection devices were worn only rarely.
Table 1. Population characteristics

\begin{tabular}{|c|c|c|c|c|c|}
\hline & TEO & Harvesters & $\begin{array}{l}\text { Livestock } \\
\text { farmers }\end{array}$ & $\begin{array}{c}\text { Grain } \\
\text { farmers }\end{array}$ & Controls \\
\hline & $N=21$ & $N=17$ & $N=38$ & $N=11$ & $N=62$ \\
\hline Age, years (range) & $\begin{array}{c}39 \\
(25-48)\end{array}$ & $\begin{array}{c}37 \\
(27-47)\end{array}$ & $\begin{array}{c}45 \\
(33-50)\end{array}$ & $\begin{array}{c}52 \\
(47-58)\end{array}$ & $\begin{array}{c}40 \\
(33-45)\end{array}$ \\
\hline $\begin{array}{l}\text { Gender: male, } \\
\mathrm{n}(\%)\end{array}$ & $\begin{array}{c}20 \\
(95 \%)\end{array}$ & $\begin{array}{c}16 \\
(94 \%)\end{array}$ & $\begin{array}{c}38 \\
(100 \%)\end{array}$ & $\begin{array}{c}11 \\
(100 \%)\end{array}$ & $\begin{array}{c}62 \\
(100 \%)\end{array}$ \\
\hline Weight, kg & $\begin{array}{c}83 \\
(75-90) \\
\end{array}$ & $\begin{array}{c}83 \\
(77-93) \\
\end{array}$ & $\begin{array}{c}83 \\
(80-92) \\
\end{array}$ & $\begin{array}{c}91 \\
(85-98) \\
\end{array}$ & $\begin{array}{c}75 \\
(68-85) \\
\end{array}$ \\
\hline Height, m & $\begin{array}{c}1.78 \\
(1.74-1.80)\end{array}$ & $\begin{array}{c}1.80 \\
(1.73-1.83)\end{array}$ & $\begin{array}{c}1.82 \\
(1.75-1.86)\end{array}$ & $\begin{array}{c}1.81 \\
(1.78-1.86)\end{array}$ & $\begin{array}{c}1.78 \\
(1.73-1.84)\end{array}$ \\
\hline $\mathrm{BMI}, \mathrm{kg} / \mathrm{m}^{2}$ & $\begin{array}{c}27 \\
(24-28)\end{array}$ & $\begin{array}{c}27 \\
(25-28)\end{array}$ & $\begin{array}{c}26 \\
(23-28)\end{array}$ & $\begin{array}{c}28 \\
(26-31)\end{array}$ & $\begin{array}{c}24 \\
(22-26)\end{array}$ \\
\hline \multicolumn{6}{|l|}{ Smoking category } \\
\hline $\begin{array}{l}\text { Current smoker, } \\
\mathrm{n}(\%)\end{array}$ & $\begin{array}{c}11 \\
(52 \%)\end{array}$ & $\begin{array}{c}7 \\
(41 \%) \\
\end{array}$ & $\begin{array}{c}7 \\
(18 \%) \\
\end{array}$ & $\begin{array}{c}2 \\
(18 \%)\end{array}$ & $\begin{array}{c}10 \\
(16 \%)\end{array}$ \\
\hline Pack-years & $\begin{array}{c}10.5 \\
(4.8-30.0)\end{array}$ & $\begin{array}{c}4.5 \\
(0.5-12.0)\end{array}$ & $\begin{array}{c}1.5 \\
(0.5-5.0) \\
\end{array}$ & $\begin{array}{c}20 \\
(20-20)\end{array}$ & $\begin{array}{c}1.1 \\
(0.9-4.6)\end{array}$ \\
\hline $\begin{array}{l}\text { Former smoker, } \\
\mathrm{n}(\%)\end{array}$ & $\begin{array}{c}4 \\
(19 \%)\end{array}$ & $\begin{array}{c}1 \\
(6 \%)\end{array}$ & $\begin{array}{c}8 \\
(21 \%)\end{array}$ & $\begin{array}{c}4 \\
(36 \%)\end{array}$ & $\begin{array}{c}21 \\
(34 \%)\end{array}$ \\
\hline Pack-years & $\begin{array}{c}10.0 \\
(4.6-19.9) \\
\end{array}$ & 7 & $\begin{array}{c}19.5 \\
(3.7-32.5)\end{array}$ & $\begin{array}{c}10.6 \\
(5.4-22.7) \\
\end{array}$ & $\begin{array}{c}4.5 \\
(0.8-13) \\
\end{array}$ \\
\hline Non-smoker, n (\%) & $\begin{array}{c}6 \\
(29 \%) \\
\end{array}$ & $\begin{array}{c}9 \\
(53 \%)\end{array}$ & $\begin{array}{c}23 \\
(61 \%) \\
\end{array}$ & $\begin{array}{c}5 \\
(45 \%) \\
\end{array}$ & $\begin{array}{c}31 \\
(50 \%) \\
\end{array}$ \\
\hline $\begin{array}{l}\text { Clinical atopy }{ }^{a} \text {, } \\
\mathrm{n}(\%)\end{array}$ & $\begin{array}{c}2 \\
(9.5 \%)\end{array}$ & $\begin{array}{c}1 \\
(5.9 \%)\end{array}$ & $\begin{array}{c}1 \\
(2.6 \%)\end{array}$ & - & $\begin{array}{c}4 \\
(6.5 \%)\end{array}$ \\
\hline
\end{tabular}

Data are expressed as Median (Interquartile range)

${ }^{a}$ at least one allergic rhinitis, eczema or other allergies non related to work

Harvesters are exposed to wheat grain or straw dust during the wheat-harvesting season from beginning of July - end of August in the Vaud region. Their tasks consist of conducting the harvester or the straw maker, controlling the harvesting process, cleaning the machine for half-an-hour every day, and for two to three hours at the end of the harvesting season and making small repairs. Machines with high-efficiency particulate absorption (HEPA) filters were used most of the time. The workers' exposure to wheat dust occurred mostly during everyday cleaning and intervention on the machines, which was typically completed without personal protection, and during grain unloading from lorries when the door of the cab was left open.

Livestock farmers are exposed to wheat dust and hay dust almost all year round. Their tasks consist of handling straw balls, with or without mechanical equipment, and distributing it as bedding for livestock. The frequency of this task is 3-5 times a week, from October - April, and 1-3 times a week from April - October. Some farmers also make straw balls during the summer. This population is mostly exposed to wheat dust during the direct handling of straw or straw balls.

Grain farmers are currently the grain-related population least exposed to wheat dust. This population is exposed to wheat dust only during grain unloading on the docks of the terminal elevators.

Exposure assessment. A detailed occupational history including job title, workplace, start and stop date, tasks undertaken with their duration and frequency, technological changes during their career, and collective and personal 
protective devices used - was obtained by questionnaire from each participant.

The actual workplace of each participant was visited by an occupational hygiene specialist to assess semi-quantitative wheat-dust exposure levels for each task undertaken. Based on the previous assessments $[7,14]$ and few personal exposure measurements of total dust (unpublished data), an exposure level ranging from $0-5$, with a rough factor of 2 between the levels of exposure to wheat dust concerning the amount of total dust inhaled per cubic meter, was assigned to each wheat related task performed by each participant. The presence and/or wearing of protective devices were considered for the exposure level assigned (Tab. 2).

Table 2. Matrix of exposure to wheat dust for all wheat related tasks

\begin{tabular}{lcc}
\hline Operation & $\begin{array}{c}\text { Level of } \\
\text { exposure }\end{array}$ & $\begin{array}{c}\text { Estimated total } \\
\text { dust concentration } \\
\text { in } \mathrm{mg} \mathrm{m}^{-3}\end{array}$ \\
\hline Grain harvesters & & \\
\hline Threshing with no cab & 5 & 24 \\
\hline Threshing with cab, HEPAa filter & 2 & 3 \\
\hline Harvester cleaning & 5 & 24 \\
\hline
\end{tabular}

\begin{tabular}{lcc}
\hline Straw harvesters & & \\
\hline Straw making, open cab & 3 & 6 \\
\hline Straw making, closed cab, no HEPA filter & 2 & 3 \\
\hline Direct handling of straw bales & 3 & 6 \\
\hline Mechanically assisted handling of straw bales & 1 & 1.5 \\
\hline
\end{tabular}

\section{Operators in grain elevators}

\begin{tabular}{lll}
\hline Unloading grain, at $5 \mathrm{~m}$ from unloading dock & 3 & 6 \\
\hline Unloading grain, at $1 \mathrm{~m}$ from unloading dock & 4 & 12 \\
\hline Unloading grain, from open office & 3 & 6 \\
\hline Unloading grain, from closed office & 1 & 1.5 \\
\hline Silo cleaning & 5 & 24
\end{tabular}

\section{Livestock farmers}

\begin{tabular}{lll}
\hline Open straw bales & 2 & 3 \\
\hline Spread straw as litter for animals & 3 & 6 \\
\hline a HEPA filter: High-efficiency particulate absorption filter &
\end{tabular}

To assess the effects of exposure to wheat dust on health outcomes, the following were defined: 1 indicator for recent exposure to wheat dust, 2 indicators for the chronic exposure in the last 10 years: the cumulative exposure and mean annual exposure, and 2 others for chronic exposure of the overall carer: the cumulative exposure to wheat dust and mean annual exposure for the overall carer.

The indicator for the individual recent exposure to wheat dust was based on the assessed occupational level of exposure to wheat dust within 6 weeks before the medical visit, although the indicators for the chronic exposure overall carer and in the last 10 years were based on the job history provided by each volunteer.

The study subjects were divided into 3 groups, defined as follows: not exposed to wheat dust in the last 6 weeks, exposed to low and medium levels of wheat dust (tasks assigned with a level 1-3 in Table 2) and exposed to high levels of wheat dust (levels 4 and 5).

The following formulas were applied:

for the duration of the exposure to wheat dust, respectively, in the last 10 years $\left(\mathrm{D}_{10 \mathrm{y}}\right)$ and overall carer $\left(\mathrm{D}_{\text {tot }}\right)$ :

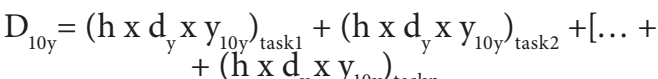

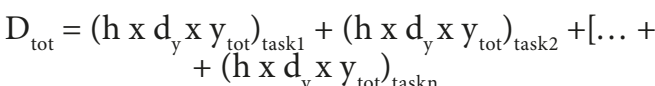

where

$\mathbf{h}$ is the number of exposing hours per day;

$\mathbf{d}_{\mathbf{y}}$ - the number of days in which the task was performed per year;

$\mathbf{y}_{10 \mathrm{y}}$ - the number of years in which the task was performed in the last 10 years;

$\mathbf{y}_{\text {tot }}$ - the number of years in which the task was performed overall carer

for the recent exposure to wheat dust $\left(\mathrm{E}_{6 \mathrm{w}}\right)$ and the cumulative chronic exposure, respectively, in the last 10 years $\left(\mathrm{E}_{10 \mathrm{y}}\right)$ and overall carer $\left(\mathrm{E}_{\text {tot }}\right)$ :

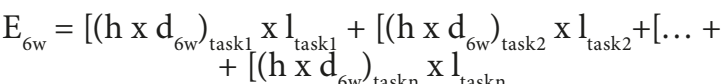

$$
\begin{aligned}
& \mathrm{E}_{10 \mathrm{y}}=\left[\left(\mathrm{h} \mathrm{x} \mathrm{d}_{\mathrm{y}} \mathrm{x} \mathrm{y}_{10 \mathrm{y}}\right)_{\text {task } 1} \mathrm{x} \mathrm{l}_{\text {task } 1}^{6 \mathrm{w}}+\left[\left(\mathrm{h} \mathrm{x} \mathrm{d}_{\mathrm{y}} \mathrm{x} \mathrm{y}_{10 \mathrm{y}}\right)_{\text {task } 2} \mathrm{xl}_{\text {task } 2}+\right.\right. \\
& +\left[\ldots+\left[\left(\mathrm{hx} \mathrm{d}_{\mathrm{y}} \mathrm{x} \mathrm{y}_{10 \mathrm{y}}\right)_{\text {taskn }} \mathrm{x} \mathrm{l}_{\text {taskn }}\right.\right. \\
& \mathrm{E}_{\text {tot }}=\left[\left(\mathrm{hxd}_{\mathrm{y}} \mathrm{x}_{\text {tot }}\right)_{\text {task1 } 1} \times \mathrm{l}_{\text {task } 1}+\left[\left(\mathrm{h} \mathrm{x} \mathrm{d}_{\mathrm{y}} \mathrm{xy}_{\text {tot }}\right)_{\text {task2 }} \times \mathrm{l}_{\text {task2 }}+\right.\right. \\
& +\left[\ldots+\left[\left(\mathrm{hx} \mathrm{d}_{\mathrm{y}} \mathrm{x} \mathrm{y}_{\text {tot }}\right){ }_{\text {taskn }} \mathrm{x} \mathrm{l}_{\text {taskn }}\right.\right.
\end{aligned}
$$

where

$\mathbf{1}_{\text {taskn }}$ is the level of exposure to wheat dust during the task ' $n$ ' estimated in Table 2;

$\mathbf{d}_{6 \mathrm{w}}$ - the number of days in which the task was performed in the 6 weeks before the medical visit, which yielded a value in hours.mg. $\mathrm{m}^{-3}$.

Annual mean exposure in the last 10 years and overall carer were obtained, respectively, by dividing the cumulative chronic exposure indices $\mathrm{E}_{10 \mathrm{y}}$ and $\mathrm{E}_{\text {tot }}$ by the number of years of work exposure to wheat dust.

To estimate the possible confounding exposure to hay dust, separate cumulative exposure indicators were computed under the assumption that the level of hay dust was similar to the level of exposure to wheat dust in the tasks exposing to hay dust.

Collection of work-related symptoms. The respiratory symptoms were collected by a trained nurse following a questionnaire adapted from the European Coal and Steel Community questionnaire [15]. Acute respiratory symptoms were defined by the presence of the symptoms listed in Table 4 during the last 12 months. Systemic symptoms were defined by the presence of any of the following: headache, fatigue, muscles aches or fever. Chronic symptoms were defined by the presence of cough or phlegm symptoms for at least 3 months during the last 2 years. Usual respiratory problems were defined by the presence of any usual subjective respiratory troubles, non-spontaneously reversible, reported by the subject. Work-related symptoms were defined as any symptoms present during the working days, and improving or disappearing at night, during the weekend or on holidays. 
Table 3. Exposure data of study population

\begin{tabular}{|c|c|c|c|c|}
\hline & TEO & Harvesters & $\begin{array}{l}\text { Livestock } \\
\text { farmers }\end{array}$ & $\begin{array}{l}\text { Grain } \\
\text { farmers }\end{array}$ \\
\hline & $\mathrm{N}=21$ & $\mathrm{~N}=17$ & $\mathrm{~N}=38$ & $\mathrm{~N}=11$ \\
\hline Working time, years & $\begin{array}{c}24 \\
(9-31)\end{array}$ & $\begin{array}{c}16 \\
(11-25)\end{array}$ & $\begin{array}{c}27 \\
(17-32)\end{array}$ & $\begin{array}{c}35 \\
(32-41)\end{array}$ \\
\hline $\begin{array}{l}\text { Wheat related working time }{ }^{\text {a }} \text {, } \\
\text { years }\end{array}$ & $\begin{array}{c}11 \\
(5-23)\end{array}$ & $\begin{array}{c}16 \\
(7-25)\end{array}$ & $\begin{array}{c}25 \\
(17-32)\end{array}$ & $\begin{array}{c}34 \\
(31-37)\end{array}$ \\
\hline $\begin{array}{l}\text { Annual wheat related } \\
\text { working time }{ }^{\text {b }} \text {, hours/year }\end{array}$ & $\begin{array}{c}252 \\
(189-344)\end{array}$ & $\begin{array}{c}188 \\
(108-318) \\
\end{array}$ & $\begin{array}{c}130 \\
(71-176) \\
\end{array}$ & $\begin{array}{c}180 \\
(35-249)\end{array}$ \\
\hline $\mathrm{D}_{10 y^{\prime}}$ multiples of 100 hours & $\begin{array}{c}\mathbf{2 2 . 7} \\
(12.6-32.3)\end{array}$ & $\begin{array}{c}15.2 \\
(6.4-28.2)\end{array}$ & $\begin{array}{c}11.4 \\
(5.8-18.5)\end{array}$ & $\begin{array}{c}0.8 \\
(0.1-11.4)\end{array}$ \\
\hline $\mathrm{D}_{\text {tot' }}$ multiples of 100 hours & $\begin{array}{c}30.2 \\
(12.7-58.1) \\
\end{array}$ & $\begin{array}{c}28.2 \\
(12.7-56.7) \\
\end{array}$ & $\begin{array}{c}31.1 \\
(11.4-47.9) \\
\end{array}$ & $\begin{array}{c}\mathbf{5 5 . 8} \\
(11.2-88.6) \\
\end{array}$ \\
\hline $\begin{array}{l}D_{\text {tot }}>6 \mathrm{mg} \cdot \mathrm{m}^{-3}, \text { multiples of } \\
100 \text { hours }\end{array}$ & $\begin{array}{c}1 \\
(0-440)\end{array}$ & $\begin{array}{c}74 \\
(0-238)\end{array}$ & $\begin{array}{c}21 \\
(0-222)\end{array}$ & $\begin{array}{c}40 \\
(0-1680) \\
\end{array}$ \\
\hline $\begin{array}{l}\text { Number of subjects exposed } \\
\text { to }>6 \mathrm{mg} \cdot \mathrm{m}-3, \mathrm{n}(\%)\end{array}$ & $\begin{array}{c}11 \\
(52 \%)\end{array}$ & $\begin{array}{c}12 \\
(71 \%)\end{array}$ & $\begin{array}{c}24 \\
(63 \%)\end{array}$ & $\begin{array}{c}7 \\
(64 \%)\end{array}$ \\
\hline $\mathrm{E}_{6 w^{\prime}} \mathrm{mg} \cdot \mathrm{m}^{-3}$ & $\begin{array}{c}3 \\
(3-6) \\
\end{array}$ & $\begin{array}{c}3 \\
(3-6) \\
\end{array}$ & $\begin{array}{c}6 \\
(3-6) \\
\end{array}$ & $\begin{array}{c}0 \\
(0-1.5) \\
\end{array}$ \\
\hline $\mathrm{E}_{10 \mathrm{y}^{\prime}} 100$ h.mg.m ${ }^{-3}$ & $\begin{array}{c}153 \\
(60-180)\end{array}$ & $\begin{array}{c}81 \\
(35-128) \\
\end{array}$ & $\begin{array}{c}72 \\
(26-104) \\
\end{array}$ & $\begin{array}{c}3 \\
(0.8-84) \\
\end{array}$ \\
\hline Annual $\mathrm{E}_{10 \mathrm{y}}{ }^{\mathrm{d}}, \mathrm{mg} \cdot \mathrm{m}^{-3}$ & $\begin{array}{c}6.0 \\
(4.5-6.9) \\
\end{array}$ & $\begin{array}{c}4.0 \\
(3.5-5.3) \\
\end{array}$ & $\begin{array}{c}5.1 \\
(3.9-6.0) \\
\end{array}$ & $\begin{array}{c}6.0 \\
(4.0-6.0) \\
\end{array}$ \\
\hline $\mathrm{E}_{\text {tot' }^{\prime}} 100$ h.mg.m ${ }^{-3}$ & $\begin{array}{c}191 \\
(68-364)\end{array}$ & $\begin{array}{c}140 \\
(47-214)\end{array}$ & $\begin{array}{c}163 \\
(85-228)\end{array}$ & $\begin{array}{c}540 \\
(67-633)\end{array}$ \\
\hline Annual $\mathrm{E}_{\mathrm{tot}}{ }^{\mathrm{c}}, \mathrm{mg} \cdot \mathrm{m}^{-3}$ & $\begin{array}{c}6.0 \\
(4.6-6.9)\end{array}$ & $\begin{array}{c}4.8 \\
(3.7-6.0)\end{array}$ & $\begin{array}{c}5.8 \\
(4.6-6.1)\end{array}$ & $\begin{array}{c}6.3 \\
(6.0-11.1)\end{array}$ \\
\hline
\end{tabular}

Data are expressed as Median (Interquartile range)

Significant values are in bold

a No. of years with wheat-related working activity

${ }^{\mathrm{b}} \mathrm{No}$. of hours per year with wheat-related working activity

cAnnual mean exposure overall carer

${ }^{\mathrm{d}}$ Annual mean exposure in last 10 years

Collection of spirometric parameters. Lung function was assessed using an electronic spirometer (EasyOne ${ }^{\circledast}$ device, NDD, Zürich, Switzerland), and following 2005 ATS/ERS guidelines [16]. After a maximal inspiration, volunteers performed forced expiratory manoeuvres. Maximal values from three reproducible measurements were obtained for Forced Vital Capacity (FVC), Forced Expiratory Volume in 1 second $\left(\mathrm{FEV}_{1}\right)$, and Peak Expiratory Flow (PEF). Predicted values according to age and height by gender for spirometric parameters were computed following the 2005 ERS prediction equations [17].

Sampling of exhaled nitrogen monoxide. The exhaled fraction of nitrogen monoxide $\left(\mathrm{F}_{\mathrm{E}} \mathrm{NO}\right)$ was used as a surrogate marker for eosinophilic airway inflammation [18]. $\mathrm{F}_{\mathrm{E}} \mathrm{NO}$ was measured by an electrochemical analyser (NIOX MINO device; Aerocrine ${ }^{\varpi}$, Stockholm, Sweden). The subject expired slowly through a mouthpiece with a nose clip, against a pressure of $5 \mathrm{~cm} \mathrm{H}_{2} \mathrm{O}$ at a rate of $50 \mathrm{ml} . \mathrm{s}^{-1}$ for 10 seconds, following the manufacturer's recommendations. This manoeuvre was repeated for 3 concordant values of $\mathrm{F}_{\mathrm{E}} \mathrm{NO}$ (difference $<10 \%$ ). The value of $\mathrm{F}_{\mathrm{E}} \mathrm{NO}$ corresponding to the mean of these 3 measurements was noted.

Statistical methods. The effects of the different exposure indices on the health outcomes were assessed using multiple linear regressions for spirometric parameters, and logtransformed $\mathrm{F}_{\mathrm{E}} \mathrm{NO}$ (in ppb) and multiple logistic regressions for the prevalence of respiratory symptoms. For spirometric values, the regression was adjusted on predicted values to account for age and height. Furthermore, all regressions were adjusted for confounders, such as smoking in pack-years and by smoking status (non-smoker, former and current smokers). The potential confounding effects of exposure to hay dust were assessed by adjusting for the estimated cumulative exposure from the tasks related to these activities.

Ethics. The study was approved by the Human Research Ethics Committee of Vaud, Switzerland (Protocol No. 130/12). Written informed consent was provided by all participants.

\section{RESULTS}

Exposure to wheat dust. Although the annual mean exposure index was similar between the different working groups exposed to wheat dust, the recent and chronic exposure patterns of these populations were quite different (Tab. 3). A decrease in the duration of exposure tasks to wheat dust was observed in the last 10 years for all working populations handling wheat. However, although a spectacular decrease was observed for the grain farmers, a smaller decrease was observed for the other exposed populations (by roughly a factor of 2.7 for livestock farmers, 1.9 for harvesters and 1.3 for the TEO) (Tab. 3). A decrease in the cumulative exposure to wheat dust was also observed in the last 10 years. This decrease was impressive for the grain farmers $\left(E_{10 y}\right.$ represents only $0.5 \%$ of $\mathrm{E}_{\text {tot }}$ ) moderate for livestock farmers and harvesters ( $\mathrm{E}_{10 \mathrm{y}}$ represents $44 \%$ and $58 \%$, respectively, of $\left.\mathrm{E}_{\text {tot }}\right)$, but low for TEO $\left(\mathrm{E}_{10 \mathrm{y}}\right.$ represents $80 \%$ of $\left.\mathrm{E}_{\text {tot }}\right)$. However, no significant decrease in the annual mean exposure level was noticed in the past decade.

Respiratory health effects of recent exposure to wheat dust. Five of the 7 acute symptoms collected were significantly more frequent in the working groups exposed to wheat dust than in those not exposed (Tab. 4). When only recent exposure to wheat dust was considered, significant trends were found for all acute symptoms between exposed and non-exposed subjects (Tab. 4). However, among exposed subjects, significant trends with recent exposure score were only confirmed for the frequency of scratchy throat $(\mathrm{p}=0.018$, data not shown).

Considering the impact of recent exposure to wheat dust on lung function, only an increase in the exposure level from level 4-5 was significantly associated with a decrease in PEF (-1490 ml.s ${ }^{-1}$; 95\% CI -2786; -193), increased FVC (536 $\mathrm{ml} ; 95 \%$ CI 57; 1015) and a decrease of the corresponding ratio $\mathrm{FEV}_{1} / \mathrm{FVC}$ (-6.462\%; 95\% CI -11.462; -1.462) (Tab. 5). The only noteworthy feature for $\mathrm{F}_{\mathrm{E}} \mathrm{NO}$ (Tab. 4 and Tab. 5) was a lower value among terminal elevator operators than among controls.

Respiratory health effects of chronic exposure to wheat dust. No difference in the prevalence of chronic symptoms - self-declared asthma, chronic cough and/or phlegm, usual respiratory problems - was found between the groups exposed to wheat dust and those not exposed (Tab. 4). However, for the usual respiratory problems, an increasing trend with recent exposure level to wheat dust was found to be significant $(\mathrm{p}=0.025$, data not shown). 
Table 4. Acute and chronic work-related respiratory symptoms prevalence, spirometric parameters and $\mathrm{F}_{\mathrm{E}} \mathrm{NO}$

\begin{tabular}{|c|c|c|c|c|c|c|c|}
\hline & TEO & Harvesters & Livestock farmers & Grain farmers & Controls & \multirow{2}{*}{$\begin{array}{l}p \text {-value for } \\
\text { group }\end{array}$} & \multirow{2}{*}{$\begin{array}{l}\mathrm{p} \text {-value for trend } \\
\text { with recent exposure }\end{array}$} \\
\hline & $N=21$ & $N=17$ & $N=38$ & $N=11$ & $N=62$ & & \\
\hline \multicolumn{8}{|l|}{ Acute symptoms } \\
\hline Acute cough, n (\%) & $9(42.9)$ & $7(41.2)$ & $17(44.7)$ & $5(45.5)$ & $2(3.2)$ & $0.002^{\mathrm{a}}$ & $<0.001^{b}$ \\
\hline Wheezing, n (\%) & $7(33)$ & $3(17.7)$ & $5(13.2)$ & $3(27.3)$ & $3(4.8)$ & $0.11^{\mathrm{a}}$ & $0.02^{\mathrm{b}}$ \\
\hline Dyspnoea, n (\%) & $6(29.6)$ & $4(23.5)$ & $9(23.7)$ & $3(27.3)$ & $1(1.6)$ & $0.06^{\mathrm{a}}$ & $0.001^{b}$ \\
\hline Runny/stuffy nose, n (\%) & $6(28.6)$ & $8(47.1)$ & $9(23.7)$ & $1(9.1)$ & $7(11.3)$ & $0.03^{a}$ & $0.006^{b}$ \\
\hline Sneezing, n (\%) & $6(28.6)$ & $6(35.3)$ & $5(13.2)$ & - & $4(6.5)$ & $0.02^{a}$ & $0.008^{b}$ \\
\hline Scratchy throat, n (\%) & $9(42.9)$ & $5(29.4)$ & $3(7.9)$ & - & $6(9.7)$ & $0.02^{a}$ & $0.03^{b}$ \\
\hline Systemic, n (\%) & $1(4.8)$ & $6(35.3)$ & $4(10.5)$ & $2(18.2)$ & $2(3.2)$ & $0.01^{\mathrm{a}}$ & $0.02^{\mathrm{b}}$ \\
\hline \multicolumn{8}{|l|}{ Chronic symptoms } \\
\hline Self-declared adult-onset asthma, n (\%) & - & - & $1(2.6)$ & - & $4(6.4)$ & - & - \\
\hline Usual respiratory problems, n (\%) & $8(38.1)$ & $4(23.5)$ & $7(18.4)$ & $3(27.3)$ & $6(9.7)$ & $0.19^{a}$ & $0.025^{b}$ \\
\hline \multicolumn{8}{|l|}{ Lung function } \\
\hline FEV1 \% predicted, mean (SD) & $93.6(20.8)$ & $96.2(15.4)$ & $101.4(14.0)$ & $89.2(17.9)$ & $98.9(12.9)$ & $0.62^{c}$ & $0.45^{d}$ \\
\hline FVC \% predicted, mean (SD) & $97.6(14.8)$ & $103.8(15.4)$ & $104.7(14.1)$ & $93.3(10.6)$ & $102.5(12.0)$ & $0.12^{c}$ & $0.20^{d}$ \\
\hline FEV1/FVC \% predicted, mean (SD) & $97.6(12.5)$ & $95.7(9.8)$ & $99.4(7.2)$ & $97.4(10.3)$ & $99.3(8.1)$ & $0.58^{c}$ & $0.37^{d}$ \\
\hline PEF \% predicted, mean (SD) & $96.2(20.6)$ & $94.4(19.2)$ & $105.0(19.4)$ & $101.7(18.1)$ & $107.6(17.3)$ & $0.19^{c}$ & $0.05^{d}$ \\
\hline $\mathrm{F}_{\mathrm{E}} \mathrm{NO} \mathrm{ppb}$, mean (SD) & $10.9(6.2)$ & $14.8(9.5)$ & $20.0(8.8)$ & $19.4(7.3)$ & $20.9(14.8)$ & $0.003^{c}$ & $0.30^{d}$ \\
\hline
\end{tabular}

Table 5. Impact of a recent exposure to wheat dust on lung function

\begin{tabular}{|c|c|c|c|c|c|}
\hline & $\mathrm{FEV}_{1} \mathrm{ml}^{\mathrm{a}}$ & $\begin{array}{c}\mathrm{FEV}_{1} / \mathrm{FVC} \\
\%^{\mathrm{a}}\end{array}$ & $\mathrm{FVC} \mathrm{ml}^{\mathrm{b}}$ & $\mathrm{PEF} \mathrm{ml} / \mathrm{s}^{\mathrm{a}}$ & $\begin{array}{l}\mathrm{F}_{\mathrm{E}} \mathrm{NO} \\
\mathrm{ppm}^{\mathrm{c}}\end{array}$ \\
\hline Controls & - & - & - & - & - \\
\hline \multicolumn{6}{|l|}{$(\mathrm{N}=62)$} \\
\hline Elevator operators & -4 & 0.51 & -84 & -752 & $-0.488^{* *}$ \\
\hline$(\mathrm{N}=21)$ & $\begin{array}{c}(-315 \\
308)\end{array}$ & $\begin{array}{c}(-3.131 \\
4.151)\end{array}$ & $\begin{array}{c}(-428 \\
261)\end{array}$ & $\begin{array}{c}(-1681 \\
177)\end{array}$ & $\begin{array}{c}(-0.769 \\
-0.208)\end{array}$ \\
\hline Grain harvesters & 3 & -2.856 & 199 & $-1132^{*}$ & -0.249 \\
\hline$(\mathrm{N}=17)$ & $\begin{array}{c}(-323 ; \\
329)\end{array}$ & $\begin{array}{c}(-6.668 \\
0.955)\end{array}$ & $\begin{array}{c}(-169 \\
568)\end{array}$ & $\begin{array}{c}(-2105 ; \\
159)\end{array}$ & $\begin{array}{c}(-0.539 \\
0.041)\end{array}$ \\
\hline Livestock farmers & 91 & -0.265 & 117 & -304 & 0.054 \\
\hline$(\mathrm{N}=38)$ & $\begin{array}{c}(-147 \\
328)\end{array}$ & $\begin{array}{c}(-3.039 \\
2.510)\end{array}$ & $\begin{array}{c}(-151 ; \\
386)\end{array}$ & $\begin{array}{c}(-1012 ; \\
405)\end{array}$ & $\begin{array}{c}(-0.153 \\
0.262)\end{array}$ \\
\hline Grain farmers & 239 & 0.586 & -422 & -233 & 0.072 \\
\hline$(\mathrm{N}=11)$ & $\begin{array}{c}(-622 ; \\
144)\end{array}$ & $\begin{array}{c}(-3.896 \\
5.068)\end{array}$ & $(-845 ; 1)$ & $\begin{array}{c}(-1377 ; \\
910)\end{array}$ & $\begin{array}{c}(-0.258 \\
0.402)\end{array}$ \\
\hline Controls & - & - & - & - & - \\
\hline \multicolumn{6}{|l|}{$(\mathrm{N}=62)$} \\
\hline$E_{6 w}=0$ & $-508 *$ & -0.729 & $-710 * *$ & -670 & 0.248 \\
\hline$(\mathrm{N}=8)$ & $\begin{array}{c}(-940 \\
-77)\end{array}$ & $\begin{array}{c}(-5.774 \\
4.317)\end{array}$ & $\begin{array}{c}(-1184 ; \\
-237)\end{array}$ & $\begin{array}{c}(-1979 ; \\
638)\end{array}$ & $\begin{array}{c}(-0.139 \\
0.635)\end{array}$ \\
\hline $\mathrm{E}_{6 \mathrm{w}}<6 \mathrm{mg} \cdot \mathrm{m}^{-3}$ & 69 & 0.283 & 51 & -400 & -0.173 \\
\hline$(\mathrm{N}=71)$ & $\begin{array}{c}(-134 ; \\
271)\end{array}$ & $\begin{array}{c}(-2.080 \\
2.646)\end{array}$ & $\begin{array}{c}(-175 ; \\
277)\end{array}$ & $\begin{array}{c}(-1013 ; \\
213)\end{array}$ & $\begin{array}{c}(-0.361 \\
0.016)\end{array}$ \\
\hline $\mathrm{E}_{6 \mathrm{w}}>6 \mathrm{mg} \cdot \mathrm{m}^{-3}$ & 96 & $-6.462^{*}$ & $536 *$ & $-1490^{*}$ & 0.178 \\
\hline$(\mathrm{N}=8)$ & $\begin{array}{c}(-331 ; \\
524)\end{array}$ & $\begin{array}{l}(-11.462 \\
-1.462)\end{array}$ & $(57 ; 1015)$ & $\begin{array}{l}(-2786 ; \\
-193)\end{array}$ & $\begin{array}{c}(-0.213 \\
0.570)\end{array}$ \\
\hline
\end{tabular}

${ }^{*} p<0.05 ;{ }^{* *} p<0.01$
When the spirometric parameters were modelled as a function of the chronic exposure indices to wheat dust (Tab. 6), an increase in the annual mean exposure level

Table 6. Chronic impact of exposure to wheat dust on lung function

\begin{tabular}{|c|c|c|c|c|}
\hline & FEV1 $(\mathrm{ml})^{\mathrm{a}}$ & FEV1/FVC (\%) & $\mathrm{FVC}(\mathrm{ml})^{\mathrm{b}}$ & $\operatorname{PEF}(\mathrm{ml} / \mathrm{s})^{\mathrm{a}}$ \\
\hline \multicolumn{5}{|c|}{$\begin{array}{l}\text { Model 1: exposed vs. non-exposed, duration of exposure and annual mean } \\
\text { exposure }\end{array}$} \\
\hline $\begin{array}{l}\text { exposed/non- } \\
\text { exposed }\end{array}$ & $\begin{array}{c}366^{*} \\
(53 ; 678)\end{array}$ & $\begin{array}{c}2.779 \\
(-0.901 ; 6.458)\end{array}$ & $\begin{array}{c}287 \\
(-76 ; 651)\end{array}$ & $\begin{array}{c}127 \\
(-812 ; 1067)\end{array}$ \\
\hline $\begin{array}{l}\mathrm{D}_{\text {tort }} \text { multiples of } \\
100 \mathrm{~h}\end{array}$ & $\begin{array}{c}-2 \\
(-6 ;-1)\end{array}$ & $\begin{array}{c}-0.001 \\
(-0.041 ; 0.039)\end{array}$ & $\begin{array}{c}-4 \\
(-0.008 ; 0.000)\end{array}$ & $\begin{array}{c}4 \\
(-0.006 ; 0.014)\end{array}$ \\
\hline $\begin{array}{l}\text { Annual } \mathrm{E}_{\mathrm{tot}} \\
\mathrm{ng} \cdot \mathrm{m}^{-3}\end{array}$ & $\begin{array}{c}-40^{*} \\
(-73 ;-7)\end{array}$ & $\begin{array}{c}-0.484^{*} \\
(-0.873 ;-0.094)\end{array}$ & $\begin{array}{c}-18 \\
(-57 ; 20)\end{array}$ & $\begin{array}{c}-123^{*} \\
(-222 ;-23)\end{array}$ \\
\hline
\end{tabular}

\section{Model 2: exposed vs. non-exposed and cumulative exposure}

\begin{tabular}{lllll}
\hline exposed/non- & 123 & -0.094 & 0.155 & -566
\end{tabular}
exposed $\quad(-96 ; 343) \quad(-2.700 ; 2.512) \quad(-0.097 ; 0.407) \quad(-1233 ;-100)$

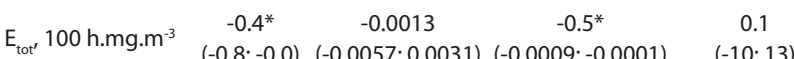

Model 3: exposed vs. non-exposed and duration of high level exposure

\begin{tabular}{lllll}
\hline exposed/non- & 74 & -0.066 & 71 & -433
\end{tabular} exposed $\quad(-124 ; 273) \quad(-2.425 ; 2.294) \quad(-157 ; 300) \quad(-934 ; 68)$

$\mathrm{D}_{\text {tot }}>6 \mathrm{mg} \cdot \mathrm{m}^{-3}, \quad-20^{*} \quad-0.126 \quad-20^{*} \quad-2$

multiples of $100 \mathrm{~h} \quad(-36 ;-4) \quad(-0.315 ; 0.063) \quad(-38 ;-1)$

Between brackets: $95 \% \mathrm{Cl}$.

${ }^{*} p<0.05$

a Difference with predicted values of the European Respiratory Society, adjusted on gender, smoking category and pack-years among smokers

${ }^{b}$ Difference with predicted values of the European Respiratory Society, adjusted on gender and smoking category

FEV1- Forced expiratory volume in 1 second

FVC - Forced vital capacity

PEF - Peak expiratory flow 
(Annual $\left.\mathrm{E}_{\text {tot }}\right)$, the lifetime cumulative exposure $\left(\mathrm{E}_{\text {tot }}\right)$ or the duration of exposure to more than $6 \mathrm{mg} \cdot \mathrm{m}^{-3}$ of wheat dust $\left(\mathrm{D}_{\text {tot }}>6 \mathrm{mg} \cdot \mathrm{m}^{-3}\right)$ was significantly associated with a decrease in FEV respectively, by approximately $40 \mathrm{ml}, 0.4 \mathrm{ml}$ per 100 h.mg. $\mathrm{m}^{-3}$ and $20 \mathrm{ml}$ per 100 hours of exposure to more than $6 \mathrm{mg} \cdot \mathrm{m}^{-3}$ of inhaled wheat dust. Similarly, an increase in the lifetime cumulative exposure $\left(\mathrm{E}_{\text {tot }}\right)$ and the duration of exposure to high levels of wheat dust $\left(D_{\text {tot }}>6 \mathrm{mg} \cdot \mathrm{m}^{-3}\right)$ was found to be significantly associated with decreased FVC by approximately $0.5 \mathrm{ml}$ per 100 h.mg. $\mathrm{m}^{-3}$ and $20 \mathrm{ml}$ per $100 \mathrm{~h}$ of exposure to more than $6 \mathrm{mg} \cdot \mathrm{m}^{-3}$ of wheat dust, respectively. In contrast, only an increase in the annual mean exposure level to wheat dust (Annual $\mathrm{E}_{\text {tot }}$ ) was significantly associated with decreased PEF by approximately $123 \mathrm{ml} . \mathrm{s}^{-1}$. With respect to symptoms, the prevalence of usual respiratory problems increased with lifetime cumulative exposure to wheat dust $(\mathrm{p}=0.042$, data not shown). No other symptoms were related to chronic exposure indicators. No association was observed between chronic exposure and $\mathrm{F}_{\mathrm{E}} \mathrm{NO}$ levels.

When the quantitative hay exposure index was considered, no additional statistically significant effects could be shown, for either the spirometric parameters or the $\mathrm{F}_{\mathrm{E}} \mathrm{NO}$ levels. The regression coefficients for the exposure indices with respect to wheat dust remained significant after adjustment for hay dust, suggesting no negative confounding effects.

\section{DISCUSSION}

A semi-quantitatively assessment was performed to study the present-day and previous exposure of workers to wheat dust, and the respiratory health effects related to the handling of wheat grain or/and straw, according to the actual methods of exposure. It was found that the different working populations exposed to wheat dust - farmers, harvesters and terminal elevator operators - presented similar overall mean exposure indices, but with different exposure patterns. Despite this difference and the decrease in wheat dust exposure in the last 10 years, the respiratory health (both symptoms and lung function) of all wheat-related worker populations was still found to have been affected.

Present exposure levels to wheat dust. Considerable changes in the technology and work practice in the grain industry have occurred in the past decade. The mechanical assistance for grain and straw handling decreased the level of exposure to wheat dust of workers $[7,14]$. However, these changes did not decrease as much as expected the duration and the cumulative exposure to wheat dust for livestock farmers, harvesters and TEOs. These results are explained by the strong increase in volume of the grain or straw handled, and the maintenance of high-exposure tasks associated with cleaning and maintenance by fewer workers.

Health effects of recent exposure to wheat dust. The presented results show that the actual exposing tasks to wheat dust still specifically induced acute respiratory symptoms in worker populations exposed to wheat dust, even after accounting for smoking. In addition, the results of the statistical tests for trends performed in this study indicate the existence of a dose-response symptomatic pattern related to recent wheat dust exposure, which confirms the results of previous studies [19]. However, these findings should be interpreted with caution as dose-response relationships remained significant only for scratchy throat when only the populations exposed to wheat dust are included in the model. Considering the impact of recent exposure on lung function, the PEF is the only spirometric marker that decreased with recent exposure (6 weeks). This decrease might evoke a bronchial hyperreactivity due to wheat dust exposure and, in this case, the decrease in PEF is concordant with a higher prevalence of acute respiratory symptoms. However, while PEF is used for serially monitoring the short-term small airway obstruction typical in occupational asthma (OASYS protocol) [20], it has a poor reliability as a single measurement.

Health effect of chronic exposure. Previous studies have shown that the early markers for COPD, chronic cough or sputum, were significantly more frequent in the populations exposed to wheat dust than within a non-exposed population $[19,21]$. However, these symptoms were not found in excess among workers exposed to wheat dust. One explanation for this finding could be that the reduction in the exposure to wheat dust avoided the development of these symptoms in the studied exposed population. Another explanation could be that these symptoms did not have time to appear; indeed, a portion of the population followed in the presented study had a relatively young median age, and such symptoms tend to appear later in life.

In contrast to the findings on chronic symptoms, the significant decrease in FEV1 and FVC with lifetime cumulative exposure and duration of exposure to more than $6 \mathrm{mg} \cdot \mathrm{m}^{-3}$ of wheat dust found in the present study, is consistent with the results of the previous studies conducted on grain elevators [21] or livestock farmers [5, 11, 12]. However, although statistically significant, the magnitude of the lung function decline in the current study is in line with the reduced exposure. Indeed, the observed effect of a cumulative exposure corresponding to the median exposure in this population (i.e., 3,000 h.mg.m ${ }^{-3}$ ) is a decrease in the $\mathrm{FEV}_{1}$ of approximately $12 \mathrm{ml}$. As this decrease of $\mathrm{FEV}_{1}$ corresponds approximately to the natural ageing effect of one year in a non-smoking population, the effect of exposure could be interpreted as an added ageing of one year in the exposed population [22].

A striking feature, is the very low prevalence of selfdeclared asthma among exposed subjects when compared to the Swiss general population (estimated to be $8.3 \%$ in the SAPALDIA cohort) [23]. This phenomenon could be explained by a 'healthy worker effect', as asthmatics might not be able to tolerate the dust exposure in the job. However, it could also point to a reduced sensitivity to organic dust among subjects having been exposed since childhood [24].

$\mathrm{F}_{\mathrm{E}} \mathrm{NO}$ values were not found to be associated with exposure, which suggests that the exposure to wheat dust does not induce any eosinophilic-mediated airway inflammation [18]. However, to-date, there are only a few epidemiological studies (and none among grain workers) using this marker, and the limited evidence available suggests that bronchial hyperresponsiveness is predicted by $\mathrm{F}_{\mathrm{E}} \mathrm{NO}$ increase, rather than by $\mathrm{F}_{\mathrm{E}} \mathrm{NO}$ absolute value [25]. To explore an association between $\mathrm{F}_{\mathrm{E}} \mathrm{NO}$ variation and recent exposure, a study monitoring $\mathrm{F}_{\mathrm{E}} \mathrm{NO}$ values in the same population during the low-exposure season should to be conducted. 
Strengths and weaknesses. The main strength of the presented study is that it considers the occupational exposure to wheat dust and respiratory health simultaneously for different worker populations exposed to wheat dust. One possible weakness is that this exposure assessment is specifically focused on wheat dust with less emphasis on other exposing agents, such as dust generated by the handling of other plants or plant-derived, animal-derived materials. However, the frequency of acute and chronic symptoms, as well as the spirometric parameters obtained for livestock farmers known to be exposed to hay dust, did not differ from those obtained for the other populations exposed to wheat dust, but not to hay dust. This finding indirectly supports the hypothesis that the health effects found in the presented study are mainly due to wheat dust itself.

Both positive and negative results must be interpreted bearing in mind the relatively small sample size of the studied population. Thus, while demonstrating doseresponse relationships with lifelong cumulative exposure and duration of exposure at high levels of wheat dust, the current study cannot exclude effects at somewhat lower levels of exposure to wheat dust. In addition, the study does not have sufficient power to discriminate between groups of exposed individuals.

From a strictly epidemiological point of view, the exposedcontrol comparison might be somewhat overestimated. First, the 2 groups were not strictly comparable, as the group of controls comprises a large proportion of white-collar workers in whom lifestyle-dependent factors might differ from those of the exposed workers. Second, the recruitment method used - voluntary workers - can induce a selection bias. The absence of any significant difference in health outcomes between exposed and controls, once the quantitative exposure estimates have been taken into account, suggests that these biases are not important.

\section{CONCLUSIONS}

Despite the improvements in individual and collective respiratory protective measures leading to a global decrease in the wheat dust exposure at work during the last 10 years, high-exposure tasks associated with direct cleaning and maintenance are still present. A dose-response associative pattern was found between wheat dust exposure and both respiratory symptoms and lung function, indicating a need to further improve workplace prevention. This outcome could be accomplished by offering alternative solutions for cleaning of mechanical equipment with compressed air, by encouraging instead anti-static industrial vacuum cleaning, or by finding a new cleaning solution that does not directly involve the operator. In the meantime, particular attention should be given to promoting the use of personal respiratory protective equipment, such as a filtering face piece for particles (FFP), or closed-circuit respirators for selected high-exposure tasks.

\section{Acknowledgements}

The authors express their thanks to Dr. C. Lazor-Blanchet and M. Coté for their support in recruitment of the controls, M. Porchet and D. Spinedi for assisting with data collection, Y. Randin for informatics support, and Dr. G. Rivier for the bibliographic support. The study was supported by the
Agence Nationale de Sécurité Sanitaire de l'Alimentation, de l'Environnement et du Travail (ANSES), France, by Grant No. 2011/1/087 to H. N-H, and by the Caisse nationale suisse d'assurance en cas d'accidents (SUVA) grant to PK and BD.

\section{REFERENCES}

1. [No authors listed] Respiratory health hazards in agriculture. Am J Respir Crit Care Med. 1998; 158(5 Pt 2): S1-S76.

2. Rask-Andersen A. Asthma increase among farmers: a 12-year followup. Ups J Med Sci. 2011; 116(1): 60-71.

3. Kline JN, Jagielo PJ, Watt JL, Schwartz DA. Bronchial hyperreactivity is associated with enhanced grain dust-induced airflow obstruction. J Appl Physiol. 2000; 89(3): 1172-1178.

4. Pahwa P, Senthilselvan A, McDuffie HH, Dosman JA. Longitudinal decline in lung function measurements among Saskatchewan grain workers. Can Respir J. 2003; 10(3): 135-141.

5. Chaudemanche H, Monnet E, Westeel V, Pernet D, Dubiez A, Perrin C, Laplante JJ, Depierre A, Dalphin JC. Respiratory status in dairy farmers in France; cross sectional and longitudinal analyses. Occup Environ Med. 2003; 60(11): 858-863.

6. Jouneau S, Boche A, Brinchault G, Fekete K, Guillot S, Bayat S, Desrues B. On-site screening of farming-induced chronic obstructive pulmonary disease with the use of an electronic mini-spirometer: results of a pilot study in Brittany, France. Int Arch Occup Environ Health. 2012; 85(6): 623-630.

7. Spankie S, Cherrie JW. Exposure to grain dust in Great Britain. Ann Occup Hyg. 2012; 56(1): 25-36.

8. Halstensen AS, Nordby KC, Wouters IM, Eduard W. Determinants of microbial exposure in grain farming. Ann Occup Hyg. 2007; 51(7): 581-592.

9. Eduard W, Pearce N, Douwes J. Chronic bronchitis, COPD, and lung function in farmers: the role of biological agents. Chest. 2009; 136(3): 716-725.

10. Mounchetrou IN, Monnet E, Laplante JJ, Dalphin JC, Thaon I. Predictors of early cessation of dairy farming in the French Doubs province: 12-year follow-up. Am J Ind Med. 2012; 55(2): 136-142.

11. Thaon I, Thiebaut A, Jochault L, Lefebvre A, Laplante JJ, Dalphin JC. 2011. Influence of hay and animal feed exposure on respiratory status: a longitudinal study. Eur Respir J. 2011; 37(4): 767-774.

12. Venier AG, Chaudemanche H, Monnet E, Thaon I, Fury R, Laplante JJ, Dalphin JC. Influence of occupational factors on lung function in French dairy farmers. A 5-year longitudinal study. Am J Ind Med. 2006; 49(4): 231-237.

13. Senthilselvan A, Chenard L, Grover V, Kirychuk SP, Hagel L, Ulmer K, Hurst TS, Dosman JA. Excess longitudinal decline in lung function in grain farmers. J Agromedicine. 2010; 15(2): 157-165.

14. Halstensen AS, Heldal KK, Wouters IM, Skogstad M, Ellingsen DG, Eduard W. Exposure to grain dust and microbial components in the Norwegian grain and compound feed industry. Ann Occup Hyg. 2013; 57(9): 1105-1114.

15. Minette A. Questionnaire of the European Community for Coal and Steel (ECSC) on respiratory symptoms. 1987--updating of the 1962 and 1967 questionnaires for studying chronic bronchitis and emphysema. Eur Respir J. 1989; 2(2): 165-177.

16. Miller MR, Hankinson J, Brusasco V, Burgos F, Casaburi R, Coates A, Crapo R, Enright P, van der Grinten CP, Gustafsson P, Jensen R, Johnson DC, MacIntyre N, McKay R, Navajas D, Pedersen OF, Pellegrino R, Viegi G, Wanger J, Force AET. Standardisation of spirometry. Eur Respir J. 2005; 26(2): 319-338.

17. Pellegrino R, Viegi G, Brusasco V, Crapo RO, Burgos F, Casaburi R, Coates A, van der Grinten CP, Gustafsson P, Hankinson J, Jensen R, Johnson DC, MacIntyre N, McKay R, Miller MR, Navajas D, Pedersen $\mathrm{OF}$, Wanger J. Interpretative strategies for lung function tests. Eur Respir J. 2005; 26(5): 948-968.

18. Dweik RA, Boggs PB, Erzurum SC, Irvin CG, Leigh MW, Lundberg JO, Olin AC, Plummer AL, Taylor DR. An official ATS clinical practice guideline: interpretation of exhaled nitric oxide levels (FENO) for clinical applications. Am J Respir Crit Care Med. 2011; 184(5): 602-615.

19. Viet SM, Buchan R, Stallones L. Acute respiratory effects and endotoxin exposure during wheat harvest in Northeastern Colorado. Appl Occup Environ Hyg. 2001; 16(6): 685-697.

20. Gainet M, Thaon I, Westeel V, Chaudemanche H, Venier AG, Dubiez A, Laplante JJ, Dalphin JC. Development of OASYS-2: a system for 
the analysis of serial measurement of peak expiratory flow in workers with suspected occupational asthma. Thorax. 1996; 51(5): 484-489.

21. Dimich-Ward H, Beking KJ, Dybuncio A, Bartlett KH, Karlen BJ, Chow Y, Chan-Yeung M. Respiratory health of two cohorts of terminal grain elevator workers studied 30 years apart. Am J Ind Med. 2011; 54(4): 263-268.

22. Kerstjens HA, Rijcken B, Schouten JP, Postma DS. Decline of FEV1 by age and smoking status: facts, figures, and fallacies. Thorax. 1997; 52(9): 820-827.

23. Wuthrich B, Schmid-Grendelmeier P, Schindler C, Imboden M, Bircher A, Zemp E, Probst-Hensch N. Prevalence of atopy and respiratory allergic diseases in the elderly SAPALDIA population. Int Arch Allergy Immunol. 2013; 162(2): 143-148.

24. von Mutius E, Braun-Fahrlander C, Schierl R, Riedler J, Ehlermann S, Maisch S, Waser M, Nowak D. Exposure to endotoxin or other bacterial components might protect against the development of atopy. Clin Exp Allergy. 2000; 30: 1230-1234.

25. Tossa P, Paris C, Zmirou-Navier D, Demange V, Acouetey DS, Michaely JP, Bohadana A. Increase in exhaled nitric oxide is associated with bronchial hyperresponsiveness among apprentices. Am J Respir Crit Care Med. 2010; 182: 738-744. 